\title{
Kakamega Forest, ecotourism and rural livelihoods: linkages and interactions for the Kakamega Forest region, Western Kenya
}

\author{
O. Kambona Ouma ${ }^{1} \&$ C. Stadel ${ }^{2}$ \\ ${ }^{1}$ Department of Development and Environmental Management, \\ Kenya Institute of Administration, Kenya \\ ${ }^{2}$ Department of Geography, Geology and Mineralogy, \\ University of Salzburg, Austria
}

\begin{abstract}
In view of the problem of agricultural sustainability, high human population and the precarious status of conservation efforts in the Kakamega Forest region, this study investigates the nature and extent of linkages and interactions between the adjacent Forest Community and Kakamega Forest. Using structured and semistructured interviews (questionnaire-based), in-depth interviews and discussions as well as participant observations, data was obtained from the adjacent Forest Community, top management of the Forest, operators of ecotourist facilities and tour operators to the Kakamega Forest region.

Results indicate that the adjacent Forest Community interacts with Kakamega Forest mainly in terms of resource and agricultural use. However, these interactions are largely regulated by the Forest management especially in the Northern part of the Forest which is managed as a nature reserve. Activities undertaken by the majority of the CBOs do not have a strong link to tourism. Consequently, the benefits generated from ecotourism are not sufficient enough to sustain the Community-Forest linkages and interactions. Land use activities in the Kakamega Forest region are mostly based on agriculture. This greatly influences the type and extent of human-wildlife conflict, conservation and livelihood strategies in the Region.

Keywords: ecotourism, forest management, adjacent forest community, rural livelihoods, linkages, interactions.
\end{abstract}




\section{Introduction}

Over the years, the extent of agricultural land use in and resource extraction from Kakamega Forest has increased to cope with the increasing human population which is estimated at 333 persons per square kilometre [1]. As a result, large areas of the Forest have been cleared to provide additional land for agriculture resulting into reduction in Forest size and biodiversity loss. For instance, a number of montane forest birds that formerly lived in Kakamega Forest such as Tauraco hartlaubi and Campethera tullbergi, seem to have disappeared [2].

Conservation efforts directed at the Forest have resulted into resource use restrictions as well as wildlife damage to crops especially in the Northern part of the Forest. Despite these restrictions, illegal use of Forest resources by the adjacent Forest Community to supplement their meagre incomes is still prevalent. Ecotourism activities in the Forest have not been able to reduce the high resource extraction and provide benefits that can adequately compensate for crop damages. Thus, the inter-relationship between the adjacent Forest Community and Forest management is marked by mutual mistrust and resentment. The resulting scenario poses a serious threat to the livelihoods of the Community and conservation efforts directed at the Forest.

Despite these concerns, no in-depth studies relating to the interactions between ecotourism activities, conservation priorities and rural livelihoods for the Kakamega Forest region have been conducted. Kokwaro [3] produced an overview of the illegal exploitation of the Forest resources including timber poaching, vandalism of trees (mainly stem debarking), fuel wood collection, destruction of saplings and cattle grazing. Emerton [4] and Greiner [5] documented the current and historical importance of the Forest to the local communities and the extent and type of forest utilisation by the adjacent households. Other studies, for example Bennun and Oyugi [6]; Mutangah et al. [7]; Cords et al. [8]; Cords [9, 10]; Cords and Tsingalia [11]; and Zimmerman [12] tend to have a bias towards ecological aspects of the Forest.

This study is therefore of considerable applied importance to Kenya, which like many developing countries strives to reduce poverty and conserve the environment, in an effort to achieve the millennium development goals.

\subsection{Study setting}

The study was undertaken in Kakamega Forest, Western Kenya. The Forest is the only remaining Eastern patch of the Guineo-Congolian rainforest that once stretched across Zaire, Uganda and Kenya [13-15]. The Rainforest exhibits a unique biodiversity and habitat rarity, which makes it a sanctuary for a remarkable diversity of plants, birds, insects and other forms of animal life not found anywhere else in Kenya. It is also a source to several Rivers that drain into Lake Victoria [16]. The Forest rises to an altitude of between 1500 metres to 1700 metres above sea level and located between latitudes $0^{\circ} 10^{\prime}$ and $0^{\circ} 21^{\prime}$ North and longitudes $34^{\circ} 47^{\prime}$ and $34^{\circ} 58^{\prime}$ East, (figure 1). Adjacent to the Forest in the East is the Nandi Escarpment at 2200 metres above the sea level. 
Kakamega town is located on the Western side of the Forest and at about 50 kilometres to the South, is Kisumu town. The distance from the Forest to the Ugandan border in the West is about 80 kilometres.

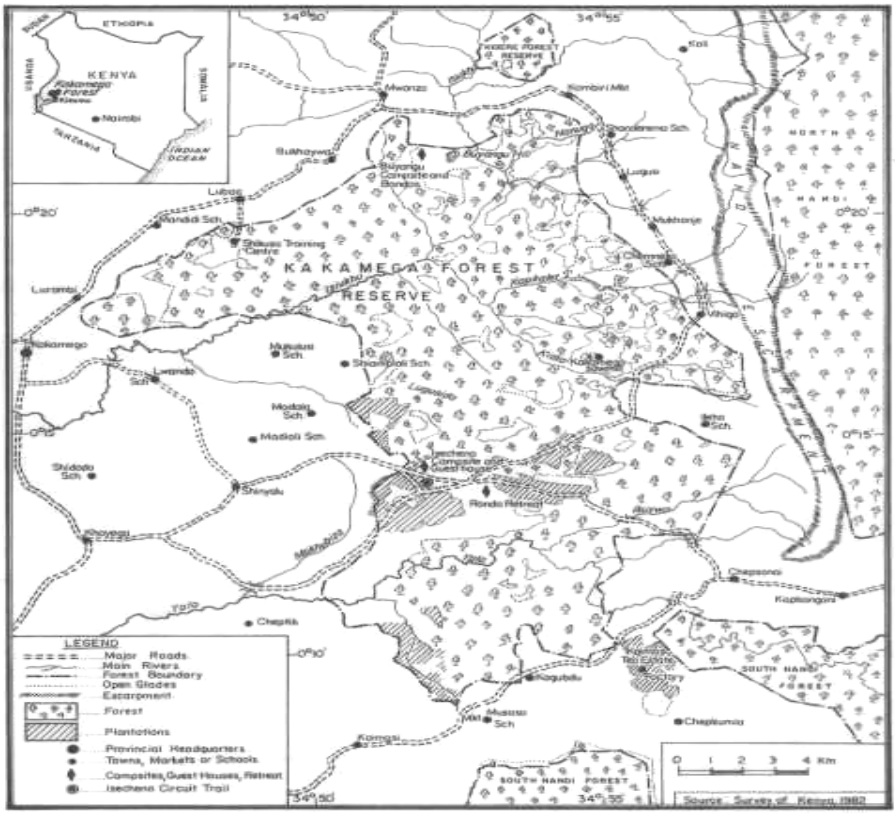

Figure 1: Kakamega Forest and associated features.

\section{Theoretical framework}

This section gives the theoretical framework that informs the present study. A critical highlight is given on ecotourism, poverty and sustainable rural livelihoods especially for adjacent forest communities.

\subsection{Ecotourism and local communities}

Ecotourism has been lauded as an attractive sustainable development alternative to mass tourism because it is perceived to have fewer negative impacts on the natural and cultural resources while providing incentives to adopt practices that conserve and potentially enhance the very resources it is dependent on $[17,18]$. However, a universally accepted framework for ecotourism in terms of concept and practice still seems elusive among scholars and practitioners. Boyd et al. [19] identifies over 35 terms that have a link to ecotourism some of which include nature travel [20]; nature-oriented tourism [21]; special interest tourism $[22,23]$; sustainable tourism and alternative tourism [24] among others. Farrel and Runyan [25], caution that the danger inherent in allowing ecotourism such a scope is that the term can fall a prey to indiscriminate use as a catchword for almost anything that links tourism with nature. Thus, this study looks at ecotourism from the ethical values and principles as given by Wight [26]. 
Since tourism greatly depends on the support and cooperations of the local communities [27], benefits accrued from ecotourism are likely to be optimised if the local people are given the opportunity to actively participate in ecotourism. Ecotourism further creates opportunities for diversification through new forms of ecological enterprises [28]. Other benefits of involving local people in ecotourism include increased employment opportunities, diversification of the local economy, increased market for agricultural products, and improved transportation infrastructures [29].

\subsection{Forests, poverty and sustainable rural livelihoods}

Although poverty has in the past been expressed on the basis of income levels or consumption, these definitions are now widely accepted to be limiting as they do not adequately capture the local complexity and dynamism of poverty. The World Bank [30] gives a broader definition of poverty as a pronounced state of deprivation of well-being related to lack of material income or consumption, low levels of education and health, vulnerability and exposure to risk, no opportunity to be heard and powerlessness. In an attempt to reduce poverty, a new approach termed sustainable livelihood which builds on the wider meaning of poverty has increasingly received acceptability within international organisations such as the World Bank, the Food and Agricultural organisation (FAO), the Department for International Development (DFID), among others. Sustainable livelihood comprises of the capabilities, assets and activities required for a means of living [31]. Bebbington [32] indicates that in this broader context, assets are not just limited to resource use but should also give people the capability to act.

In the context of forests and rural communities, forests provide livelihood assets in form of timber, non-timber forest products (NTFP) and services. The NTFP include a wide range of goods for domestic use and for market, among which are charcoal, firewood, game, fruits, honey, medicinal herbs, forage, and thatch grass. Local communities may also benefit from ecological forest services such as protection of water catchment areas [33] as well as restoration of soil fertility in agro-forestry systems [34].

Dove [35] argues that the net benefits of NTFPs are often too low to justify articulation of property rights, which in turn, limits the incentives to invest and increase yields. This is because natural forests are often inferior production environments with undeveloped infrastructure, high transport costs, few buyers and exploitative market chains. In view of these characteristics, he concludes that it is difficult for those who rely upon NTFPs to rise out of poverty thus, making NTFPs to be poverty traps. Whether it is poverty that causes forest adjacent communities to use NTFPs or their dependence on NTFPs that makes them poor is still a subject of debate.

Despite the importance that forests play in poverty alleviation, it is still difficult to ascertain the number of people who are dependent on forests because such an assessment depends on how forest dependence is defined [36, 37]. Byron and Arnold [38] have identified three categories of forest users: forest dwellers, including hunters and gatherers; farmers living adjacent to forests including small holders and the landless; and commercial users for example 
wood-based artisans, traders, small entrepreneurs and employees of forest industries. Among the user categories, there has been a widely held belief that the poor, especially those living adjacent to forests, are responsible for forest degradation. Arnold and Bird [39], in an attempt to highlight the complex link between poverty and forests, distinguish between direct and indirect causes of deforestation. They argue that forest degradation is rarely caused by direct factors alone but behind them may be a whole array of indirect factors each more remote from the forest. They give the example of conversion of forest for subsistence agriculture (a direct cause) which may be a result of population increase, policy failures within and beyond the forest sector, market failures, and civil unrest among others. They caution that the scenario may be more complex as many of the underlying causes are linked and reinforce each other.

Micro-level studies by Arnold and Bird [39 p. 2] show that poverty may result in a shortage of options forcing people to clear forests for cultivation or to use the natural resources in an unsustainable way. Nevertheless, they indicate that the poor can and do invest considerable time and resources to forest management. According to the authors, the relationship between forests and livelihoods is a matter of perspective. What might be defined as deforestation by an ecologist can be an improvement of livelihood options through an alternative use of the land for the local people. Linkages between poverty and forests would therefore be better understood by conducting in-depth studies on a case by case basis rather than making generalisations hence the present study.

\section{Methods of data collection}

Structured and semi-structured interviews (questionnaire-based), in-depth interviews and discussions were used to gather data. Participant observations and informal talks with the adjacent Forest Community and visitors to the Forest also formed valuable methods for data collection. The data collected refer to the linkages and interactions between the adjacent Forest Community and Kakamega Forest in terms of benefits obtained from the Forest, involvement in forest conservation, activities of community-based organisations, land use, and community-wildlife conflicts. Data on services provided by tour and ecotourist facility operators to the Community and Kakamega Forest was also collected.

The respondents from the adjacent Forest Community were selected on the basis of the human settlement pattern in the Kakamega Forest region and the distance of homesteads from the Forest boundary. Significant interactions of the Community with the Forest exist within 10 kilometers from the Forest boundary [40]. Thus, community members were drawn from the five settlement regions of Buyangu, Isecheno, Kibiri, Ileho (Mukhanje, Lugusi and Shanderema areas) and Ikuywa (Musasa, and Kagubdu areas) (figure 1). The selection of households was done at various distances of 3 kilometres; 3 to 6 kilometres; and 6 to 10 kilometres from the Forest boundary in the five settlement areas using stratified random sampling. Subsequently, a sample size of 241 respondents was obtained. Community members participating in in-depth discussions were selected based on their knowledge in conservation, tourism and development 
issues in the Region as well as their geographical distribution within the main settlement areas. In-depth interviews were held with key informants from the Forest Department, the Kenya Wildlife Service, Ecotourist facilities and Tour operators to Kakamega Forest. Community based organisations (CBOs) whose activities exhibited linkages to rural livelihoods and conservation of the Forest were considered for interviews. According to these criteria, Bukhaywa village conservation committee; the Kambiri environmental conservation group; the Muliro farmers conservation group; the Khaega-Shibuye forest conservation community and the Kakamega environmental education programme (KEEP) were chosen for in-depth interviews and discussions.

\section{Study findings and discussions}

The majority of the households $(69 \%)$ benefit from the Forest. The number of household beneficiaries decreases with increasing distance from the Forest boundary $\left(\chi^{2}=25.538, \alpha=0.000, \mathrm{n}=241\right)$. The nature of benefits derived include resource extraction (firewood, charcoal, thatch grass, vines, timber, and cattle grazing); food (wild honey, fruits, vegetables and fish); medicinal plants; traditional and religious use (circumcision ceremonies); and ecological assets associated with the Forest such as water resources, scenic qualities and fresh air. Owing to the benefits obtained from the Forest, the households strongly felt that the Forest should be conserved $\left(\chi^{2}=96.937, \alpha=0.000, \mathrm{n}=241\right)$.

Activities carried out by Community based organizations (CBOs) in the Forest region include raising and selling tree seedlings, bee-keeping, fish and vegetable farming, community surveillance of Forest threats, cultivating, extracting and selling medicinal plants, environmental education programme, research and guiding services, butterfly rearing, sale of souvenirs and re-forestation in the Forest. The Forest management has supported the initiatives of the CBOs by providing land on which the activities are carried out. Although schools have been built and learning materials provided by the Management using part of revenue generated from tourism, this has been sporadic and limited to a few CBOs in the Northern part of the Forest. Activities such as butterfly farming, extraction and sale of medicinal plants, and guiding services being relatively well established in the Forest, provide regular income to the CBOs. However, raising and selling of tree seedlings and beekeeping, though core to most CBOs in the region, are nevertheless operated on a small scale and greatly depend on the climatic seasons. As a result, they are not able to adequately provide viable economic alternatives.

The main ecotourist facility in the Forest is Rondo Retreat. It purchases items such as decoration flowers, manure, vegetables, meat and chicken from the local people. Even though some of the food items are purchased locally, the meals that are served to visitors at the Retreat do not have the local traditional flair as they are generally of an international standard. Similarly, most of the souvenirs like sculptures, pictures, and postcards sold at Rondo Retreat depict cultures and landscapes which are from outside the Region. The Retreat supports Forest management through re-forestation of open spaces in the Forest and maintenance of forest roads and trails. It has also provided employment opportunities to local 
people. Of the 36 employees in the Retreat, 31 of them are people from the local community. However, most of them are in low-level positions with almost half being employed as casuals; having received no training for their jobs [41].

All the six tour operation companies interviewed are owned by Kenyans. Although there are other destinations visited by the Companies in the Western Kenya tourist circuit (for example Mount Elgon National Park and Lake Turkana), each of the companies organise between 2 to 5 trips annually to Kakamega Forest. Regarding local spending and linkages with the Region, most of the tour Companies indicated that they purchase their supplies such as food and beverage in major towns outside Kakamega region such as Nairobi or Kisumu. Similarly, most of the companies brought along their catering staff from Nairobi. Tourists, especially international ones, carried along beverages like tea and sugar from their home countries. Although these practices may be convenient to the companies, they deny the Community opportunities to gain financially from tourism. Thus, most of the tour companies are yet to create strong linkages with the Forest region in terms of local spending and services.

Crop cultivation is widespread in the region accounting for $76 \%$ of the households interviewed. As a result, the activity is not influenced by household distance from the Forest boundary $\left(\chi^{2}=13.219, \alpha=0.040, n=223\right)$. The main crops grown include beans, potatoes and maize. Other land use activities are mixed farming (17\%); establishment of building sites, planting of napier grass and ox-pulled jaggery (7\%). Although prevalent in the region, intensive crop cultivation is carried out by households owning less than 2 acres of land. Those with large land parcels tend to sell or lease their land. The size of land owned by households therefore significantly influences land use activities in the Kakamega Forest region $\left(\chi^{2}=23.054, \alpha=0.001, \mathrm{n}=222\right)$. As majority of households (72\%) live within 6 kilometres from the Forest boundary and primarily use their land for crop cultivation, it is no doubt that the Forest is experiencing a major conservation threat.

Since land use activities influence the type of human-wildlife conflict $\left(\chi^{2}=29.408, \alpha=0.003, n=143\right)$, households within 3 kilometres from the Forest boundary frequently experience damage to crops by wildlife. Of the households surveyed, $63 \%$ indicated having experienced damages to crops by wildlife. Due to this conflict, some households have shifted from the food crops (maize, beans and potatoes) to cultivation of cash crops such as sugarcane and tea as these crops are considered less vulnerable to wildlife damage. However, because of the crop damage and high capital investment associated with cash crop cultivation, Community members unable to cope have abandoned their lands meant for farming. The abandoned land in some areas is leased out to people from outside the Kakamega Forest region who use it for cultivation of cash crops. Other forms of conflict include harm to human (7\%), harm to livestock and wildlife (7\%) and multiple conflicts involving at least any two of the above mentioned conflicts (23\%). The human-wildlife conflict in the Kakamega region has adverse livelihood implications for the adjacent Forest Community. In an attempt to earn a livelihood, some of the Community members lease land for cultivation far away from the Forest where damages to crops are considered less severe. Apart 
from the long time that is taken to reach the leased farms, the community members also have to pay for a land lease fee of between Kshs 1500 to Kshs 2000 (Approximately US\$ 20 to US\$ 30) per hectare. Those unable to lease land have resorted to other forms of livelihoods such as quarrying and bicycle taxi operations.

\section{Summary and conclusion}

The adjacent Forest Community interacts with Kakamega Forest mainly in terms of resource and agricultural use. However, these interactions are largely regulated by the Forest management especially in the Northern part of the Forest which is managed as a nature reserve. Activities undertaken by majority of the CBOs do not have a strong link to tourism. Consequently, the benefits generated from ecotourism are not sufficient enough to sustain the Community-Forest linkages and interactions. Land use activities in the Kakamega Forest region are mostly based on agriculture. This greatly influences the type and extent of human-wildlife conflict, conservation and livelihood strategies in the region.

Attaining a balance between conservation of Kakamega Forest, ecotourism benefits, and the rural livelihoods in the Kakamega Forest region is precarious. However, developing comprehensive integrated rural development strategies which address the problem of agricultural sustainability and the precarious status of conservation efforts is essential for the Kakamega Forest region. Determining the sustainability point at which the Community livelihoods would co-exist with conservation strategies is still a challenge as such a balance is a value judgement. Active involvement and empowerment of the Community in the management of the Forest is definitely an important pillar towards achieving the co-existence.

\section{References}

[1] Kenya Government, Kakamega District management plan (2002-2008), Government printers: Nairobi p. 8, 2002.

[2] Birdlife International, http://www.birdlife.org

[3] Kokwaro, J.O., Conservation status of the Kakamega Forest in Kenya: The easternmost relic of the equatorial rain forests of Africa. Monogr. Syst. Bot. Missouri Bot. Garden 25, pp. 471-489, 1988.

[4] Emerton, L., Summary of Findings on Forest Utilisation in Kakamega Forest. Kenya Indigenous Forest Conservation Programme (KIFCON): Nairobi, 1992.

[5] Greiner, A., Nature Conservation and Local people at Kakamega Forest, ASA Project, Final Report: Stuttgart, 1991.

[6] Bennun, L.A., \& Oyugi, J.O., Using birds to monitor environmental change in Kakamega Forest, Unpublished report, Kenya Indigenous Forest Conservation Programme: Nairobi, 1994.

[7] Mutangah, J.G., Mwangangi, O.M. \& Mwaura, P.K., Kakamega Forest Vegetation Survey, Kenya Indigenous Forest Conservation Programme/National Museums of Kenya: Nairobi, 1992.

[8] Cords, M., Fashing, P.J., Forrestel, A., \& Scully, C. Long - term tree population dynamics and their implications for the conservation of the 
Kakamega Forest, Kenya. Biodiversity and Conservation 13, pp. $753-771,2004$.

[9] Cords, M. Mixed - species association of Cercopithecus monkeys in the Kakamega Forest, Kenya. University of California Publications in Zoology 117, pp. 1-109, 1987.

[10] Cords, M. A., Mixed - species association of Cercopithecus monkeys in the Kakamega Forest, Kenya. Unpublished Ph.D. Thesis, University of California, Berkeley, 1984.

[11] Cords, M. \& Tsingalia H.M., A report on Harmful Exploitation of Indigenous Forest in Kakamega Forest, Wildlife Conservation and Management Division, Government of Kenya: Nairobi, 1982.

[12] Zimmerman, D.A., The avifauna of Western Kenya including a bird population study, Kakamega Forest. Bulletin of the American Museum of Natural History 149, pp. 257 - 270, 1972.

[13] Cords, M. \& Tsingalia H.M., A report on Harmful Exploitation of Indigenous Forest in Kakamega Forest, Wildlife Conservation and Management Division, Government of Kenya: Nairobi, 1982.

[14] Kokwaro, J. O., Conservation status of the Kakamega Forest in Kenya: The easternmost relic of the equatorial rain forests of Africa. Monogr. Syst. Bot. Missouri Bot. Garden 25, pp. 471-489, 1988.

[15] Tsingalia, M.H., Animals and the Regeneration of an African Rainforest Tree. Unpublished Ph.D. Thesis, University of California, Berkeley, California, 1988.

[16] Ogutu, Z .A., Kakamega Forest. In Parks and people - conservation and livelihoods at the crossroads - four case histories. Regional Soil Conservation Unit/SIDA-Technical Report, 17, pp. 31 - 45, 1997.

[17] Farrel, B.H. \& Runyan, D., Ecology and Tourism. Annals of Tourism Research, 18(1), pp. 26-40, 1996.

[18] Wight, P., "Ecotourism: ethics or eco-sell?" Journal of travel research 31, pp. 3-9, 1993.

[19] Boyd, S.W., Butler, R.W., Bae, R.E., Perera, A. \& Haider, W., GIS mapping for potential areas for Ecotourism in Northern Ontario. Report for the department of Natural Resources/Forestry, Ministry of Natural Resources, Sault ste. Marie, Ontario, Canada, 1994.

[20] Laarman, J.G. \& Durst. P.B., Nature travel in the tropics, Journal of Forestry, 85(5), pp. $43-46,1987$.

[21] Durst P.B. \& Ingram, C.D., Nature Oriented tourism promotion by developing countries, Tourism Management, 9(1), pp. 39 - 43, 1998.

[22] Inskeep, E., Environmental Planning for Tourism, Annals of Tourism Research, 14(1), pp. 118-135. 1987.

[23] Weiler, B. \& Hall, C.M. (eds). Special Interest Tourism, London: Belhaven press, 1992.

[24] Scace, R.C., Grifone, E. \& Usher, R., Ecotourism in Canada. Report for the Canadian Environmental Advisory Council, Ottawa, and Ontario, Canada, 1992. 
[25] Farrel, B.H. \& Runyan, D., Ecology and Tourism. Annals of Tourism Research, 18(1), pp. 26-40, 1996.

[26] Wight, P., "Ecotourism: ethics or eco-sell?" Journal of travel research, 31, pp. 3-9, 1993.

[27] Murphy, P. E., Tourism: A community approach, New York and London: Routledge, p. 153, 1985.

[28] Karwacki, J. and Boyd, C. Ethics and Ecotourism. Business Ethics: A European Review 4(4), pp. 225 -232, 1995.

[29] World Tourism Organisation/United Nations Environment Programme (WTO/UNEP), Guidelines: Development of National Parks and Protected Areas for Tourism. Technical Report series, 13, 1992.

[30] World Bank, World Development Report 2000/2001: Attacking Poverty Oxford: Oxford University press, 2001.

[31] Department for International Development (DFID), Sustainable livelihoods guidance sheets, DFID, London, 1999.

[32] Bebbington, A., Capitals and Capabilities: A framework for analysing peasant viability, rural livelihoods and poverty in the Andes. Background paper for: Policies that work for sustainable agriculture and regenerating rural economies. IIED, London, 1999.

[33] World Resource Institute (WRI), World Resources 2000-2001: People and Ecosystems. The fraying web of life. Washington, D.C.: World Resources Institute, 2000.

[34] Sanchez, P.A., Roland, J.B. \& Roger, R., Trees, Soils, and Food Security. Philosophical Transaction of the Royal Society of London, 352 (1356), pp. 949-961, 1997.

[35] Dove, M., A Revisionist View of Tropical Deforestation and Development. Environmental Conservation, 20(1), pp. 17-24, 1993.

[36] Byron, R.N. \& Arnold J.E.M., What futures for people of the tropical forests? World Development, 27(5), pp. 789-805, 1999.

[37] Calibre Consultants and the Statistical Services Centre (SCC), Number of Forest Dependent People: A feasibility Study for DFID's Forestry Research Programme. Reading, UK: University of Reading. CIC (Cutter Information Corporation). 2000. Focus Report: Saving the Forest with a Timber Lease. Global Environmental Change Report, 12(19), pp. 1-2, 2000 .

[38] Byron, R.N. \& Arnold J.E.M., What futures for people of the tropical forests? World Development, 27(5), pp. 789-805, 1999.

[39] Arnold, J.E.M. \& Bird, P., Forests and the Poverty-Environment Nexus, A report prepared for the UNDP/EC Expert Workshop on Poverty and the Environment, Brussels, Belgium, 1999.

[40] Kambona, O.O. Personal communication, 20 June 2003, Officials of Kakamega Environmental Education Programme, Kakamega Forest, Kenya.

[41] Kambona, O.O. Personal communication, 27 June 2003, Manager, Rondo Retreat, Kakamega Forest, Kenya. 